\title{
サイズ性発現機構*
}

東京大学大学院農学生命科学研究科 磯 具明

\section{Mechanism of Paper Sizing}

\section{Akira Isogai}

Graduate School of Agricultural and Life Science, The

University of Tokyo

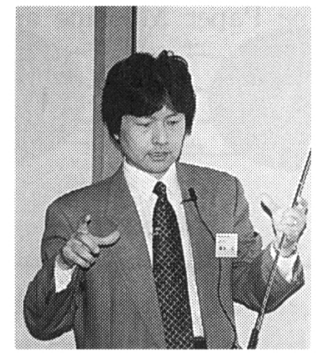

Fundamental mechanisms of paper sizing by internal sizes are reviewed on the basis of results obtained in our laboratory. Factors influencing paper sizing are explained in terms of basic theories of contact angles, changes in free energies, wettability, liquid-penetration and others. Recently, pyrolysis-gas chromatography techniques have been applied to determination of size content in paper, and thus sizing behavior can be examined in terms of size retention values. Pulp carboxyl groups and cationic compounds added at the wet-end have significant roles in size retention; electrostatic interactions among sizes, pulp fibers and fines, anionic trashes, fillers and cationic compounds in pulp suspensions are the driving force of size retention, as well as physical filtration effects. Not only size retention but also distribution of size components and changes in chemical structures of size components affect sizing behavior. SEM obsevation of AKD-sized handsheets dried at $20^{\circ} \mathrm{C}$, which had sufficient sizing levels, showed that most pulp fiber surfaces were occupied by hydrophilic cellulose and hemicellulose. Thus, complete coverage of pulp fiber surfaces with size molecules is not necessary for paper sizing, and distribution of hydrophobic size components on hydrophilic pulp fiber surfaces seems to govern the resultant sizing behavior. Solid-state ${ }^{13} \mathrm{C}$-NMR analysis of AKD-sized handsheets, extractions with either chloroform or $1 \%$ Tween 80 and SEM observations of handsheets prepared with AKD and ketone emulsions suggested that most size components were present as hydrolyzed structures without forming covalent bonds with hydroxyl groups of cellulose in paper. The structures of AKD and ASA, which can react with water and thus are somewhat hydrophilic, are necessary for paper sizing in order to avoid flocculation of the size components due to hydrophobic interactions on hydrophilic pulp fiber surfaces in papermaking process. This hypothesis of sizing mechanisms of AKD and ASA is applicable to other non-reactive sizes such as rosin soap, rosin acid emulsion and rosin-ester sizes.

*第 4 回製紙技術セミナー講演 


\section{1.はじめに}

親水性のセルロース，へミセルロースからなるパル プ繊維の集命体である紙に対して，サイズプレス，塗 L，印刷，筆渻における水系液体の紙への漫透性を 制御する日的で付りさされる機能がサイズ性である。最 近の動问としては，操業性や排水処理の間題等から， 内添サイズ処理を軽減し，ゲートロールサイズプレス 等による表间サイズ処理によって紙のサイズ性を制御 する才问にある。しかし，间時に片さ方们毛含めな紙 全体の开イズ性の確保，表洎サイズ処理の際の液体漫 透制御の日的で内添サイズ処理の重要性も指摘されて いる。また，紙のサイズ性付 ${ }^{\prime} j$ 技術は，親水性のセル ロース系材料に対して㮽好效渗的（サイズ剂添加量， 処理時間，多男の水の份在等の観焦から）に非親水的 性質を付方するものであり，その機構の解明は「效摔 的な牛物材料の收質技術」という観高からも舆味深い。 これまで，当研究突では，ロジンソープ，ロジンエマ ルション,ロジンエステル, 们消系樹脂, AKD, ASA,

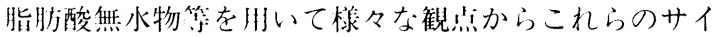
ズ発現機構を検吋してきた。そして，どの埸合も矛盾 や例外なく说明できるような゙紙のサイズ発現機構の全 体像を把持するために检刢を進めている。本セミナー では時閏の都介で,これらのサイズ発現機構のうち, 特に队添における AKD 処理を取りけげて，紙のサイ ズ性:発现機構について報售する ${ }^{1) \sim 5) 。 ~}$

\section{2. 紙のサイズ性を支配する因子}

紙のサイズ性は多くの闪「に文配されているが，基

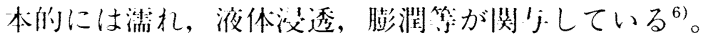

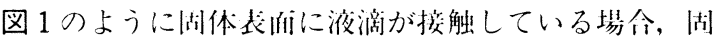

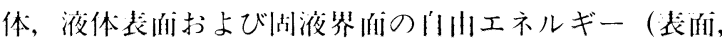

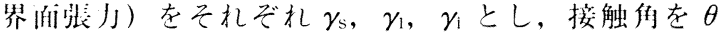
とすれば，Youngの式より，

$$
\gamma_{s}=\gamma_{i}+\gamma_{1} \cos \theta
$$

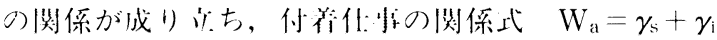

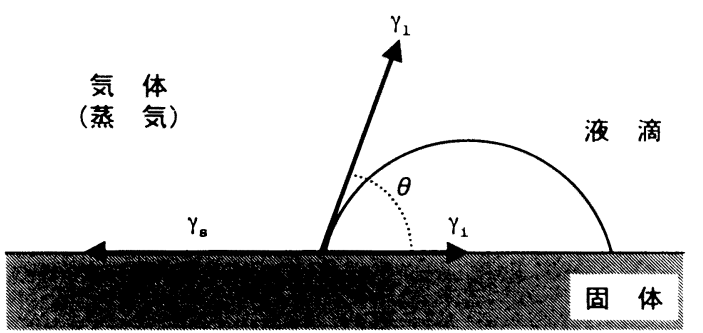

図 1 接触的と表目，界酒就力 $-\gamma_{1}$ から, Young-Duprè の式,

$$
\mathbf{W}_{\mathrm{a}}=\gamma_{1}(\cos \theta+1)
$$

が得られる。濡れには付着濡れ以外にも，拡張濡れと 浸漬濡れがあり，それぞれの仕事を $\mathrm{W}_{\mathrm{s}}, \mathrm{W}_{1}$ とすれば，

$$
\begin{aligned}
& \mathbf{W}_{\mathrm{s}}=\gamma_{\mathrm{s}}-\gamma_{\mathrm{i}}-\gamma_{1}=\gamma_{1} \quad(\cos \theta-1) \\
& \mathbf{W}_{1}=\gamma_{\mathrm{s}}-\gamma_{\mathrm{i}}=\gamma_{1} \quad(\cos \theta)
\end{aligned}
$$

と表され，接触角と液体の表面張力の関係式となる。 そして,

$\theta \leqq 180^{\circ}$ なら， $\mathrm{W}_{\mathrm{a}} \geqq 0$ で付着濡れが起こり，

$\theta \leqq 90^{\circ}$ なら， $W_{\mathrm{i}} \geqq 0$ で浸漬濡れが起こり，

$\theta \leqq 0^{\circ}$ なら， $\mathrm{W}_{\mathrm{s}}=0$ で拡張濡れが起こる。

すなわち，水が紙に接すると，未サイズ紙であれば水 の接触角はほぼゼロなので，付着濡れに続いて拡張濡 れが起こって紙は液体を吸収してしまう。サイズ紙の 場合，紙に対する水の接触角が $90^{\circ}$ 以内であれば付着 濡れにつづいて水の浸漬濡れによる浸透が始まる。一 j, 水と紙の接触角が $90^{\circ}$ 以上であれば，付着需れに 続いて水滴の凝集による接触面積の低下（水がはじく ような現象）が始まる。これらは，すべて自由エネル ギーが減少する方向に起こる。従って，表面自由エネ ルギーが大きい固体表面ほど需れやすい。

毛細管への液体の浸透量と時間との関係については, しばしばLucus-Washburn 式が引用される。

$$
\mathbf{l}^{2}=\frac{\mathbf{r} \gamma \cos \theta}{2 \eta} \mathbf{t}
$$

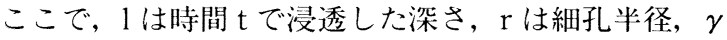
は液体の表面張力, $\theta$ は液体と紙の接触角, $\eta$ は液体 の粘度を亦す。紙に対する水浸透の場合，紙中のパル プ繊維の膨潤による細孔半径の時間変化の影響を考慮 しなければならないといわれている。しかし，ブリス ト一試験等の結果では，ある程度のサイズ度を持つサ イズ紙で，接触時間が短い範囲内の場合は，本式はほ ぼ成り立つと考えられている。この式は，紙への水浸 透を考えた場合，以下の事項を示している。

A）水の紙への浸透量は, 接触時間の $1 / 2$ 乗に比 例する。

B）水の紙に対する接触角が $90^{\circ}$ 以内であれば浸 透が始まり，接触角が小さいほど液体浸透量 が多い。

1記 A は，諳い換えると，ステキヒトサイズ度の ような紙の厚さに方向に対する水の浸透時間で表わし たサイズ度の值（ $\mathrm{t}$ 秒）は，紙の厚さの二乗に比例す ることをホしている。ステキヒトサイズ度そのものに は坪量や厚さの值が入り込まないが，紙のサイズ性を 抄紙条件やパルプを変えて評価する場合は，紙の厚さ で補正するる必要がある。 
また，ほとんどのサイズ紙のステキヒトサイズ度は 有限値なので, サイズ紙に対する水の接触角は $90^{\circ}$ 以 内であることを示している。一方， $\mathrm{AKD}$ や脂肪酸等 多くのサイズ剤のバルク固体表面に対する水の接触角 は $90^{\circ}$ 超えているので,

C)もしもサイズ剤成分が紙中のパルプ繊維表面の ほぼすべてを覆っているとすれば，紙中のサイ ズ剤成分はバルクとは異なった配向構造により， かなり小さな接触角を持つか,

D) あるいは, サイズ剤成分はパルプ繊維表面の一 部に存在し, 後述するようなCassieの接触角 によって, 見かけの接触角はかなり小さい值と なっている。

のいずれかによって説明されなければならない。いず れにしても，紙のサイズ性を支配しているのは Lucus-Washburn 式中の $\cos \theta$ の值なので, 紙に対す る水の接触角については更に検討する必要がある。紙 表面のように凸凹のある表面の場合, Wenzel の接触 角を考虑する必要がある。すなわち, 滑らかな面の面 積に対する凸们面の面積を $\mathrm{r}(\mathrm{r} \geqq 1)$ とすれば，

$$
\cos \theta_{\mathrm{w}}=\mathbf{r} \cos \theta
$$

が成り市つといわている。この式は， $\theta$ が $90^{\circ}$ 以内の 場合は $\theta_{\mathrm{w}}<\theta$ に, $\theta$ が $90^{\circ}$ 以上の場合は $\theta_{\mathrm{w}}>\theta$ になる ことを示している。すなわち, この式からは, 紙に対 する水の接触角が $90^{\circ}$ 以内とすれば，紙表面の凸以が 大きいほどサイズ度の值は小さくなる。一方，上記 D の仮定が成り立ち，もっとずっとミクロなオーダーで 紙中のサイズ剤成分（バルクの接触角は $90^{\circ}$ 以上）の 表面を見ることができたとすれば，その表面の凸凹が 大きいほど接触角は更に大きくなり，以下に示す Cassieの接触角により, 水の紙に対する接触角も大 きくなる。

水と紙の接触面が接触角 $\theta_{1}$ と $\theta_{2}$ の 2 成分からなり, それぞれ $\mathrm{A}_{1}, \mathrm{~A}_{2}$ の面積比率で存在していたとすれば, Cassieの式より, 見かけの接触角 $\theta_{\mathrm{c}}$ については,

$$
\cos \theta_{\mathrm{c}}=\mathrm{A}_{1} \cos \theta_{1}+\mathrm{A}_{2} \cos \theta_{2}
$$

が成り立つ。ここで, $\mathrm{A}_{1}+\mathrm{A}_{2}=1$ 。今, 水と紙の接 触面に空気があるとすれば，空気に対する水の接触角

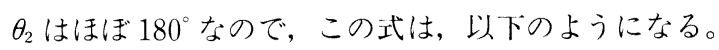

$$
\cos \theta_{\mathrm{c}}=\mathbf{A}_{1} \cos \theta_{1}-\mathbf{A}_{2}=\mathbf{A}_{1}\left(\cos \theta_{1}+1\right)-1
$$

すなわち, 紙と水の接触面に空気が存在し, 実際の紙 表面と水の接触面積比率 $\mathrm{A}_{1}$ が小さくなると, 見かけ の接触角 $\theta_{2}$ がかなり大きくなり，180近くなること がある。これら Wenzel およびCassieの接触角の影 響は，紙のサイズ性を考える場合には極めて大きい。 サトイモの葉に水滴がまるで球体のようにのっている
のは, サトイモの葉の表面に存在するロウのバルク表 面に対する水の接触角は $135^{\circ}$ であっても, 葉の表面 の凹凸が大きいため, Wenzelの接触角により見かけ の接触角は $180^{\circ}$ 付近になるためである。また，菊の 葉に朝露の水滴がまるで球体のようにのっているのは, 菊の葉の表面にロウで覆われた短毛があり, 短毛の間 に空気があるために, Cassieの見かけの接触角が $180^{\circ}$ 付近になるためである。羽毛に対する水滴や, 繊維織物に対する水滴がまるで接触角 $180^{\circ}$ 近くに見 えるのは, この空気の影響である。このように, 内添 によって紙のサイズ性を制御するには，紙に対する水 の見かけの接触角 $\theta$ の制御によって可能であることが わかる。もう一つ考虑しなければならないのは, Cassieの式の $\mathrm{A}_{1}, \mathrm{~A}_{2}$ の分布状態であり，これを関 数にして検討しなければならない。

日本では, 紙のサイズ性評価に JIS P 8122 のステ キヒトサイズ度がよく用いられる。海外ではハーキュ レスサイズテスターによる HST 值がしばしば用いら れるが，測定に用いる染料や液体（通常 $2 \%$ ギ酸水浴 液）と紙中のサイズ剤や歩留り剤の相互作用により值 が変動することが知られている。これらの 2 法は紙の 厚さ方向に対する液体の浸透挙動で評価する方法なの で, 紙の厚さに影響される。コッブ法は板紙等, サイ ズ度が高くて厚い紙には有効である。ブリスト一法で は, 弱サイズ性, 表面サイズ性の比較評価が可能であ る。

Lucus-Washburn 式によれば，紙の構造が一定で あれば液体浸透挙動は, 液体の紙に対する接触角のみ によって支配されることになる。しかし，この接触角 を測定するのは大变難しい。通常の紙では, 液滴を紙 表面に落とすと同時に浸透，膨潤が始まるので，短時 間といえどもビジュアルに観察された接触角と真の接 触角は異なってくる。ブリスト一法で水の浸透挙動を 測定すると, 弱サイズ紙については, 得られた直線部 分の傾きには明瞭な差があり, 接触角の值が得られそ うであるが，弱サイズ紙ほど紙の膨潤の影響が現れる。 また中程度以上のサイズ紙では直線部分の傾きに明瞭 な差が現れない。このように, 紙のサイズ性を理論的 に検討するのに適したサイズ性測定方法も今のところ なく，世界の標準となりそうなスタンダード的な測定 方法の淘汰にも至っていないのが現状である。

\section{3. 最近の紙中サイズ剤成分の分析技術}

従来まで, 各種サイズ撤による紙のサイズ性の評価 は，パルプサスペンションへのサイズ剤添加量に対す るサイズ度の值として評価されてきた。そして, 紙中 
のサイズ剂成分を定量するには, 時間がかかりかつ煩 雑な抽出一GC 分析操作が必要であり, かつ得られた 値の変動が大きい。一方, 最近の熱分解 GC 技術の進 展により, ロジンソープ, ロジンエマルション, ロジ ンエステル, AKD, ASA, 脂肪酸系サイズ剤について, 極めて微妙なサイズ剤含有量の差異を評価できるよう になった。すなわち, サイズ剤成分の步留り量を評価 できるようになり，紙のサイズ性を紙中のサイズ剤成 分の含有量との関係から検討できるようなった。なお, 熱分解 GCによるサイズ剤成分の最適な定量法を確立 するには，ある程度のトライアンドエラーによる条件 検討が必要で, 同じ装置でも最適条件は微妙に異なる ことが多い。また，サイズ剤の歩留り助剤であるアラ ム由来のアルミニウムは蛍光 $\mathrm{X}$ 線分析で, デンプン 誘導体は酵素分解一グルコースセンサーで, カチオン 性合成高分子は微量窒素分析によって正確な紙中含有 量が求められる。

同じ条件で抄紙した場合には, サイズ剤含有量とサ イズ度との間には明瞭な相関があり, サイズが出ない トラブルはサイズ剂步留り量が低いことによって説明 できる場合が多い。一方, 紙中サイズ剂含有量は十分 でもサイズ度が極めて低いというケースもあり，この 場合はサイズ剤そのものの問題や抄紙条件が原因とな り, トラブルシューティングの方法が見出しやすくな る。

\section{4.内添による紙のサイズ発現機構に関する これまでの考え方と問題点}

これまで提案されてきた内添サイズ剤による紙のサ イズ発現メカニズムを挙げると, まず, (1)パルプサス ペンンション中でパルプ繊維にサイズ剤成分が定着し, (2)紙の加熱乾燥過程でサイズ剤成分が溶融して広がり, (3)パルプ繊維のセルロース表面にサイズ剤分子が強く 固着し，(4)サイズ剤分子の疎水基を外側に配向させる ことにより，サイズ効果が現れるとされてきた ${ }^{77,8) 。 ~}$ (1)ではパルプ繊維表面に多量に存在する水酸基によっ てパルプ繊維表面の $\xi$ 電位がマイナスとなっているが, アラムやカチオン性高分子等の正荷電の步留り剂によ ってそ電位が中和されることにより, 添加されたサイ ズ剂成分との静電的反発が減少し, 凝集が起こって定 着する。(2)では, サイズ剤分子はパルブ繊維表面に単 分子層を形成する。(3)では, 反応性サイズ剤である $\mathrm{AKD} \mathrm{ASA}$ では，七ルロース水酸基とサイズ剂分 子間で共有結合 (エステル結合) が形成され，ロジン 一アラム系ではセルロース水酸基とロジン分子のカル ボキシル基の間にアルミニウムが介在した錯体結合を
形成する。確かに，(2)と(3)の条件が満たされて，この ような共有および錯体結合が形成されれば，(4)の条件 は自ずと満たすことになる。

しかし, 詳細な機構については上記(1)～(3)のいずれ も，すなわち, 結果的には(1)〜(4)のすべてにおいて問 題がある。まず, (1)につては, パルプ表面の $\xi$ 電位 を支配しているのは，はたして本当に水酸基であるか どうかという点。次に, (2)については, 紙の加熱乾燥 過程で本当にサイズ剂分子はパルプ繊維表面で単分子 層を形成し, 紙中のパルプ繊維表面が完全にサイズ剤 分子で覆われるのかどうか, (3については, 水が多量 に存在している抄紙系で, しかも短時間の熱乾燥過程 で，サイズ剤分子は本当にセルロース水酸基との間で 共有あるいは錯体形成できるのかどうか, という点で ある。特に, サイズ剤のような疎水性成分のウェット エンドでの凝集性の制御, プレス一乾燥工程でのパル プ繊維上での凝集性の制御は, 製造しな紙のサイズ性 を支配するはずである。

\section{5. ウェットエンドにおけるサイズ剤の歩留り 機構}

前述の熱分解 GC を利用することにより，各種サイ ズ剂の步留り機構を詳細に検討できるようになった。 そこで, AKDを例としてその歩留り機構の検討結果 を示す。内添の AKD サイズ処理では, ポリアミンポ リアドエピクロルヒドリン樹脂 (PAE) のようなカ チオン性高分子の併用添加によってサイズ度が向上す る。これについては, カチオン性の AKD エマルショ ン粒子が表面積の大きい微細繊維に多く吸着し, その 微細繊維をPAEがパルプの長繊維部分に定着して, 結果的に $\mathrm{AKD}$ の歩留り向上に寄与していると考えら れてきた。実際，図2に示すように, PAEの添加に よって紙中サイズ剤含有量が增加し, それに伴ってサ イズ度が向上している。PAEなしでも AKDの添加 量を増加させれば，それなりに AKD 成分が定着し， サイズ度も高くなる。しかし, その場合の AKDの定 着効率は低い。一方, 微細繊維を除いたファインフリ 一パルプを用いても, PAEの添加による AKDの步 留り向上, 対応するサイズ度の向上が忍められた。こ の結果は, PAEが微細繊維の歩留り向上に知与する という機構な゙けでは説明できない。

一方, $\mathrm{AKD}$ エマルションの $\xi$ 電位を, $\mathrm{pH}$ を変え て測定すると, $\mathrm{pH}$ が高くなるに連れて+の值からゼ 口付近に低下してくる。この状態でPAEを添加する と, 再び正電荷の值が復活する。すなわち, PAE 添 加による $\mathrm{AKD}$ の歩留り向上は, PAEによって $\mathrm{AKD}$ 


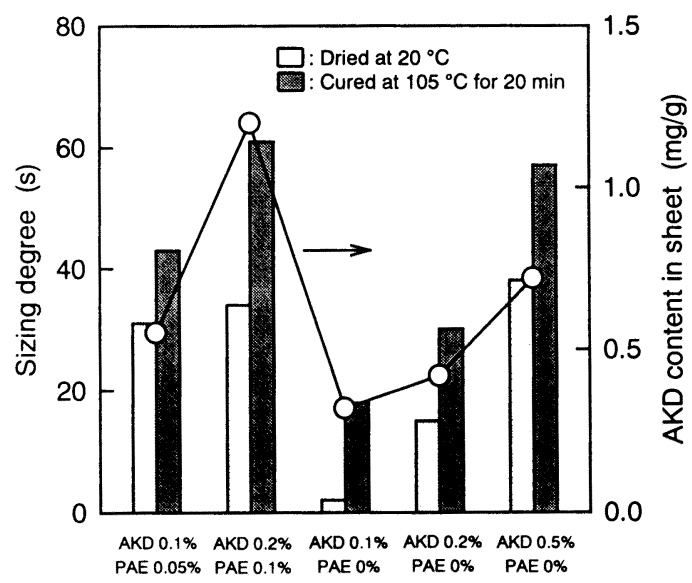

図 $2 \mathrm{AKD}$ サイジングにおける PAE 添加の影響1)

エマルション粒子表面の正電荷が補強され，それによ って, 負の表面荷電を有するパルプ纎維への定着が促 進されていることを示している。このことは, 低 $\mathrm{pH}$ で高濃度のサイズ剤エマルション原液中では表面電荷 がプラスとなって分散性が維持されている AKD エマ ルション粒子は, 希釈によって両性化し, AKDエマ ルション粒子表面にマイナスサイトが現れることを示 している。

また，パルプ繊維の負の表面電荷の本質を調べるた め, パルプ纎維中に微量に存在するカルボキシル基に 注目して検討した。パルプ中のカルボキシル基は, 一 部は木材中に元々存在しており, 一部は蒸解過程や漂 白過程で生成すると考えられている。逆滴定によって 測定すると，漂白クラフトパルプで $0.02 \sim 0.08$ $\mathrm{mEq} / \mathrm{g}$ 程度のカルボキシル基が含まれており,この 值は, 水酸基の量に比べれば確かにかなり少ない。し かし，パルプ繊維中の約 $40 \%$ を占める非晶領域にの み存在するカルボキシル基がカウントされており, カ ルボキシル基量を非晶セルロース部分の置換度として 表わすと，0.008０.03 となる。この値は市販の力チ オンデンプン中のカチオン性基量とほぼ同じであり, パルプ表面荷電にかなり大きな影響を与える值とみな すことができる。つまり，パルプ中のカルボキシル基 は, アニオン性基として十分表面荷電を支配する可能 性がある。また, パルプ中のカルボキシル基は, 通常 の化学パルプの漂白一洗浄工程でカルシウム塩型とな っていると考えられる。CMCのカルシウム塩がゲル 化するよjに，パルプ中の二つのカルボキシル基がカ ルシウム塩によって架橋されているような構造であれ ば，抒そらく解離してアニオン性を示すことはないで あろう。しかし，その意味ではパルプ中のカルボキシ
ル基どうしが架橋されるほどの量ではなく，示性式で 示せば Pulp-COOCaClのような構造を有して，十分 にパルプサスペンション中で解離し，アニオン性を持 つものと考えられる。

図 3 には，パルプ中のカルボキシル基をメチルアミ ド基でほぼ完全にブロックしたパルプを用いて AKD サイズ処理した結果を示す。この図より，パルプ中の カルボキシル基をブロックすると，AKD サイズ剤の 定着量は激減し, 対応してサイズ性は全く現れなかっ た。すなわち, 通常のサイズ剤添加量の領域では, パ ルプ中のカルボキシル基がアニオン性の接点となって, カチオン性の AKD エマルション粒子を静電的な結合 によって定着していることが明らかになった。これら の機構を図で示すと図4のようになる。しかし，カル ボキシル基をブロックしたパルプを用いた場合でも， $\mathrm{AKD}$ サイズ剤の添加量を増加させると，パルプ中の カルボキシル基がなくても $\mathrm{AKD}$ はある程度定着して サイズ性も現れる。すなわち, AKDの添加量が多く なれば, 前述した静電的な相互作用以外の凝集性, 万 過効果等によって, ある程度シート中にサイズ剤成分 を歩留めることができる。しかし，この場合は AKD の歩留り効率は極めて悪い。

四 2〜3より, AKDの歩留り率は, 手すきシート のようなモデル的条件でも $100 \%$ には至らない。まし て大きなせん断力がかかり，パルプのワンパスリテン ション率が $70 \%$ 以下の実際の抄紙マシンでは, 歩留 り効果は低くなる。しかし基本的な歩留り機構が, パ ルブ繊維表面のカルボキシル基と AKD エマルション 粒子表面との静電的な相互作用によって支配されるこ

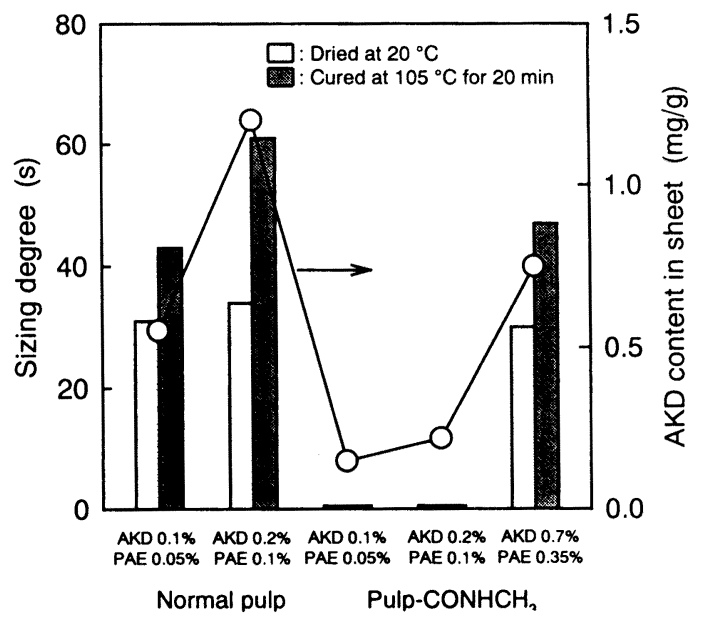

図 $3 \mathrm{AKD}$ サイジングにおけるパルプ中のカルボキ シル基の影響2) 


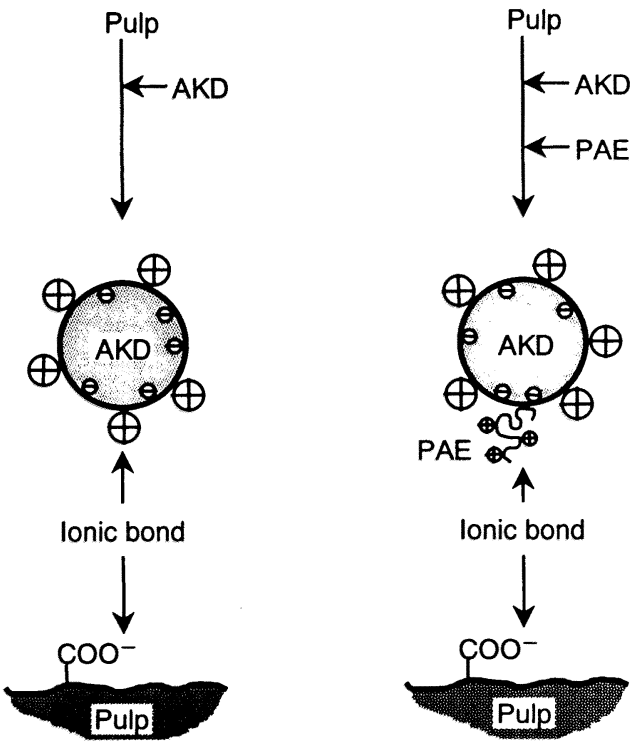

図 $4 \mathrm{AKD}$ エマルションのリテンション機構1),2)

とは事実である。また，実機でのカチオン性高分子の 併用添加による $\mathrm{AKD}$ の歩留り向上は，まさにその静 電的相互作用の制御によって達成されている。これら の歩留り機構に基づき，サイズ剤の歩留り率が $100 \%$ に至らない原因を更に追求することにより，実機にお ける更なるサイズ剤歩留り率の向上，それによる更な る添加量の低減, 污れの低減が達成できる可能性があ る。

なお，アラムを併用する ASA，ロジンソープ，口 ジンエマルション，ロジンエステル系サイズ剤の場合 は，アルミニウム成分が抄紙系の $\mathrm{pH}$ によって構造が 変化すること, アラムの添加そのものによっても抄紙 系の $\mathrm{pH}$ が変化すること，アルミニウム成分はパルプ やサイズ剤のカルボキシル基とのイオン結合形成のほ かに, 競争的に抄紙系中の水酸インとも反応して構造 が変化すること等の理由で複雑になる。アラムを歩留 り助剤とするサイズ剤の歩留り機構については, 別の 機会に紹介寸る。

\section{6. サイズ剂成分がパルプ䌜維表面で単分子層 形成する可能性について}

紙のサイズ性とは, 撥水性とは異なり, 水系液体の 浸透速度を制御するものである。したがって, 紙に対 する水の接触角は $90^{\circ}$ 以内である。そのことは, 例之 ばバルクの AKDの接触角が $90^{\circ}$ 以上であることから, サイズ剂分子による単分子層形成の可能性については, 否定的に考えざるを得ない。また，常温で固体のサイ
ズ剤は, 加熱乾燥過程で溶融する。この時, サイズ剤 成分がパルプ繊維表面に単分子層を形成するには, サ イズ剤分子どうしの凝集力よりもサイズ剤分子と水分 子（あるいはセルロース水酸基）との親水性がずっと 大きく，すなわち，サイズ剤分子にあたかも界面活性 凨のような特性が必要となる。サイズ剤成分は熱溶融 しても水中では油滴を形成しており，界面活性作用は ない。そもそも単分子層を形成することが可能なよう な界面活性㓮自身では，紙にサイズ性を付与できない。 サイズ剤成分は水に不溶で, 疎水性の強い物質でなけ ればならない。また, パルプ繊維表面はミクロな凹凸 があって構造的にも不均一であり, さらにセルロース 分子には親水面と疎水面があり, 化学的にも不均一な パルプ纎維表面に均一な単分子層を形成するのは極め て困難であり，実際，これまでにサイズ剤成分の単分 子層形成は証明されてはいない（にもかかわらず，仮 説だけが一人歩きしている)。

また，図 5 には AKDを対パルプ 0.2\%添加し, 加 熱乾燥しないで $20^{\circ} \mathrm{C}$ で緊張乾燥して作成した手すき シートの表面の SEM 写真を示す。AKD のエマルシ ヨン粒子が孤立してパルプ瀻維表面に存在しており, その他の大部分のパルプ繊維表面は親水性のセルロー ス，へミセルロースで占められている。このシートは 加熱しなくても 20 秒程度のステキヒトサイズ度を持 つ。すなわち, サイズ発現にとって加熱乾燥およびそ れに伴うサイズ剤分子の単分子層形成は必要条件では ない。熱乾燥すると AKD が溶融するため, エマルシ ヨン粒子は観察されなくなり, もちろんサイズ度は 30 秒以上に増加する。同様な結果は, ロジンエマル ションサイズでも認められた。これらの結果からも， 紙のサイズ性発現にとって, サイズ剤分子の単分子層 形成は必要なく, 実際このような単分子層形成は起こ らないといえる。すなわち, 加熱乾燥過程でサイズ剤 成分は, パルプ繊維表面上をある程度溶融一拡張一浸 透するが，依然としてパルプ纎維表面の大部分は親水 性のセルロース, ヘミセルロースに覆われている。溶 融したサイズ剤成分は海島構造のように分布しており， この状態で紙のサイズ性発現が達成されている可能性 が高い。前述のCassie の接触角の式に基づいて紙の 見かけの接触角を, サイズ剤成分 $\theta_{1}$, 空気成分 $\theta_{2}$, 親水性のセルロース・へミセルロース成分 $\theta_{3}$ に分け ると, それぞれの面積比率, $\mathrm{A}_{1}, \mathrm{~A}_{2}, \mathrm{~A}_{3}$ から, $\cos \theta_{\mathrm{c}}=\mathbf{A}_{1} \cos \theta_{1}+\mathbf{A}_{2} \cos \theta_{2}+\mathbf{A}_{3} \cos \theta_{3}$

となる。水の空気に対する接触角を $180^{\circ}$, 水のセル ロース・ヘミセルロースに対する接触角を 0 とすると, $\cos \theta_{\mathrm{c}}=\mathbf{A}_{1}\left(\cos \theta_{1}+1\right)-1+2 \mathbf{A}_{3}$ 


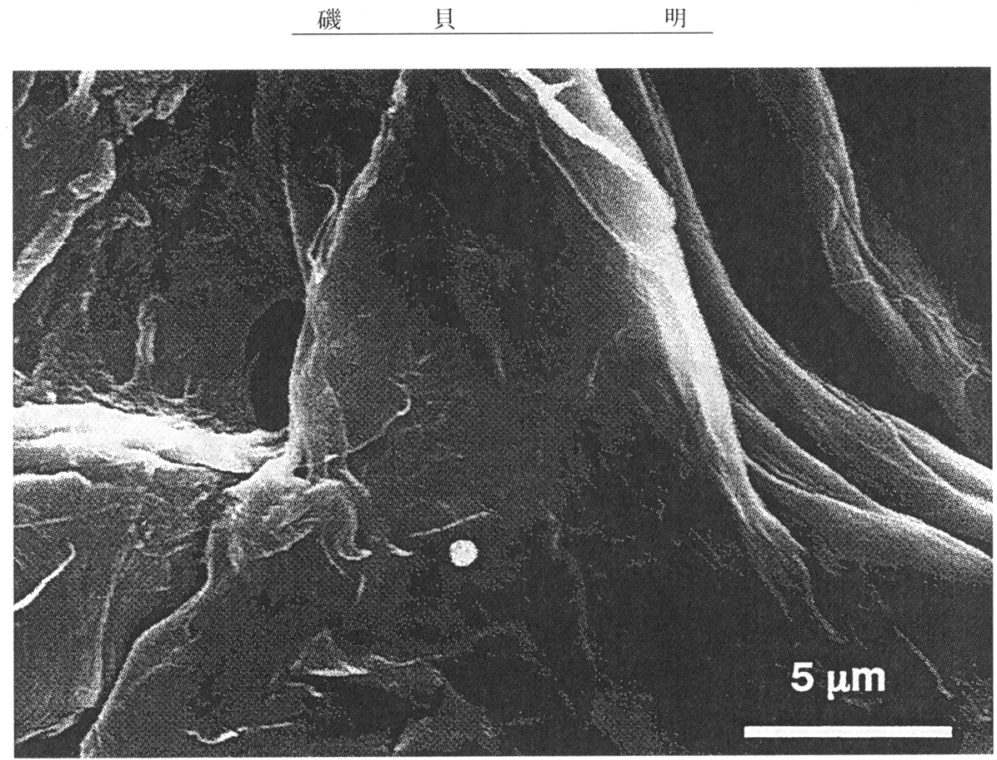

図 $50.2 \% \mathrm{AKD}$ 添加シートを $20^{\circ} \mathrm{C}$ 乾燥したシートの SEM 写真

となる。当然のことながら， $A_{1}, A_{2}, A_{3}$ 成分の分布 状態によって胃かけの接触角の值は大きく变化するは ずである。

\section{7. サイズ剤成分とパルプ中のセルロース水酸基 との共有結合形成の可能性}

AKD を例にとれば，反応性の AKD は前述した(1), (2)の過程を経て, (3)の「七ルロース水酸基との共有結 合形成」が紙の加熱乾燥工程で達成され, (4)の構造と なって効率的に紙にサイズ性が付与されるとされてき た。この仮説を支持する理由として, 以下の点が挙げ られる。

A） AKD が加水分解し, 反応性が失われたケトン ではサイズ性が現れない。すなわち, 反応性の AKDの構造がサイズに必要である。

B) AKD 処理シートをシート状でクロロホム抽出 しても，サイズ度が維持されている。これは, $\mathrm{AKD}$ 成分がセルロース水酸基とエステル結合 したために，抽出されなくなったと考えられる。 反応していないのであれば抽出されるはずであ る。

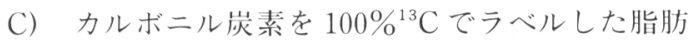
酸から合成した AKD を用いて調製したシート の固体 ${ }^{13} \mathrm{C}-\mathrm{NMR}$ 分析の結果等から, セルロ 一ス水酸基と AKD との共有結合の存在が示唆 された。

一方, $\mathrm{AKD}$ とセルロース水酸基との間の共有結合 形成に否定的になる理由として, 以下の点が挙げられ
る。

a） $\beta$-ケトエステル結合の形成には解離したセル ロース水酸基との接触が必要となるが, 七ルロ 一ス水酸基の解離度は極めて小さいこと, セル ロース水酸基よりもずっと大きな解離度を持つ 水によって生じる水酸イオンとの反応（結果的 に加水分解によってケトンが生じる）を避けて, セルロース水酸基と反応するのは困難。さらに, 含水率 10\%として紙中のパルプ繊維中の非晶 領域のセルロース水酸基 1 モルに吸着している 水分子を計算すると, 平均で 1 モル以上である。 従って, パルプ中の水酸基は孤立して存在して いるというよりも，水分子で覆われて水和した 状態である。

b) AKD 処理シートは加熱しなくてもサイズ性が 現れる。すなわち, 加熱一共有結合形成がたと えあってもサイズ発現には関係ない可能性があ る。

c）炭酸カルシウムを塡料とする中性紙では，紙中 の $\mathrm{pH}$ は 9 程度となり, エステル結合は切断さ れやすい。にもかかわらず, 中性紙にはかなり のサイズ性が維持される。経時によって中性紙 のサイズ度は低下はするが, AKDの場合には サイズ度がゼロになることはない。

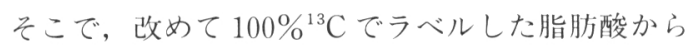
合成した $\mathrm{AKD}$ を用いて，手すきシートを作成し，固 体 ${ }^{13} \mathrm{C}-\mathrm{NMR}$ で詳細に分析する追実験をした。紙中 の $\mathrm{AKD}$ 成分の反応の可能性を図 6 に示す。その結果, 


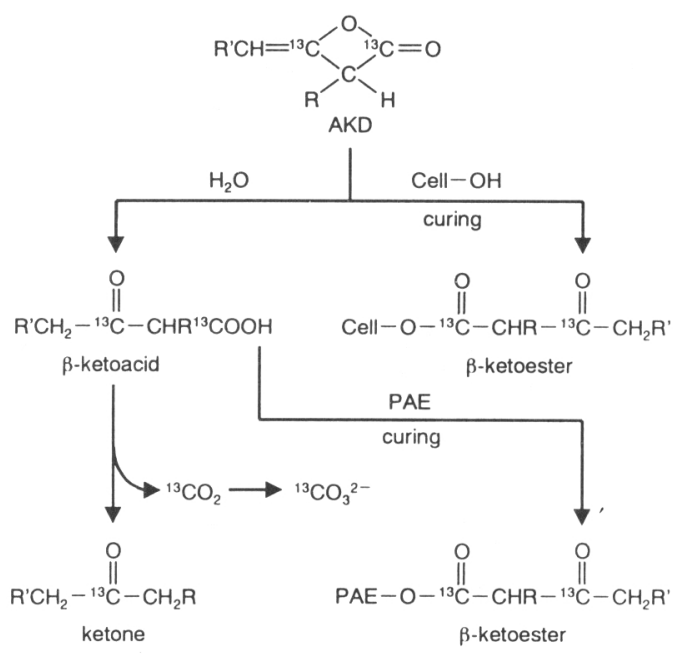

図 6 シート中で可能な $\mathrm{AKD}$ の反応 ${ }^{5)}$

上記Cのシグナルの帰属に誤りがあり，結果的に， シートの加熱の有無やPAE 添加の有無に関係なく, シート内に存在する $\mathrm{AKD}$ 成分は, もとの $\mathrm{AKD}$, 加 水分解したケトン，加水分解の際に副生する炭酸イ才 ンであることが示された。この結果は, 紙中に歩留ま った $\mathrm{AKD}$ 成分のほとんどは，七ルロース水酸基とは 共有結合せず, 結果的には加水分解してケトンとなっ てサイズ性の発現に寄与していることになる。

もしも, AKDのサイズ発現機構が, セルロース水 酸基との共有結合でないとすると、これまでの反応性 サイズ剤のサイズ発現機構を根底から覆すことになる。 同時に，上記， A， Bの事実を， AKD とセルロース 水酸基間のエステル結合以外の機構によって説明しな ければならない。

Aについては, $\mathrm{AKD}$ エマルションと $\mathrm{AKD} の$ 加水 分解によって得られたケトンのエマルションを添加し て作成した手すきシートのサイズ特性, SEM 観察か ら説明できた。四 5 で示すように, AKD エマルショ ン添加の場合はパルプ瀻維表面に孤立した AKD エマ ルション粒子が定着している。それに対し, ケトンエ マルションを用いた場合は，極めて大きなケトンの凝 集体が形成され，パルプ纎維間に親水性のパルプ繊維 との接触面積を最小にするように球体状で存在してい た(図 7)。この結果から，ケトンの構造でウェット エンドでパルプサスペンションに添加した場合は，ケ トンの強い疎水性により，サイズ剤成分が凝集してし まい，均一なサイズ㘊成分の分布が得られないために サイズ効率が低いとことが明らかになった。すなわち， AKD は抄紙系に存在する水と反応して構造変化する という, 一種の親水性により, サイズ剂成分の抄紙工

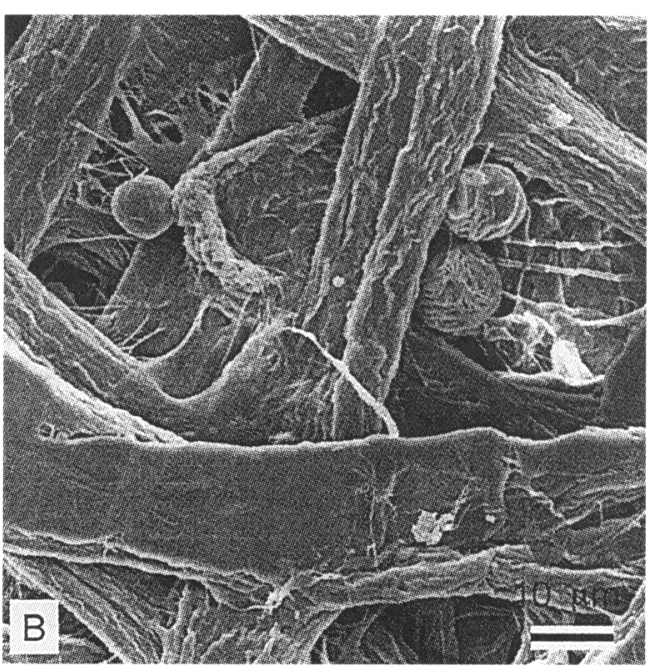

図 7 ケトンエマルション添加シートの SEM 写真

程での凝集が抑えられ，結果的にサイズ剂成分のパル プ纎維表面での均一な分布が達成される。均一な分布 が達成された後での, $\mathrm{AKD} の$ 加水分解により, 疎水 性の強いケトンに構造変化して効率的にサイズ性が発 現される（図 8)。言い換えれば，もしも，疎水性の 強いケトンを, 親水性のパルプ表面上に凝集させるこ となく，分布させることができれば，十分に効率的に サイズ性が現れるはずである。しかし，水の存在する 抄紙工程では，AKD という反応性の構造であればそ れを達成できるが，ケトンではできないことになる。

AKD サイズ処理シートのクロロホルム抽出で, サ イズ性が維持される $\mathrm{B}$ の現象については, 強い界面 活性剤である Tween 80 水溶液による解繊状態での抽 出処理の結果から説明できた。すなおち，パルプ繊維 表面で, AKDの加水分解物であるケトンとセルロー 又分子は水素結合および疎水結合によって強く固着し ており（セルロース分子鎖には親水面と疎水面があ る), シート状でのクロロホルム抽出では両者の物理 的結合を完全に切ることはできない。しかし，水系媒 体で AKD 処理シートを解繊し, Tween 80 のような 強い界面活性剤処理を行うことにより，はじめて分離 できる。従って, クロロホルム抽出に対するサイズ剤 成分の抽出抵抗をセルロース水酸基との共有結合形成 によって説明する必要はない。

$\mathrm{AKD}$ 処理シートあるいは ASA 処理シートの経時 によるサイズ度の低下，すなおち，デサイジング挙動 については，サイズ剤成分とセルロース水酸基との間 で形成されたエステル結合の部分的なアルカリ加水分 


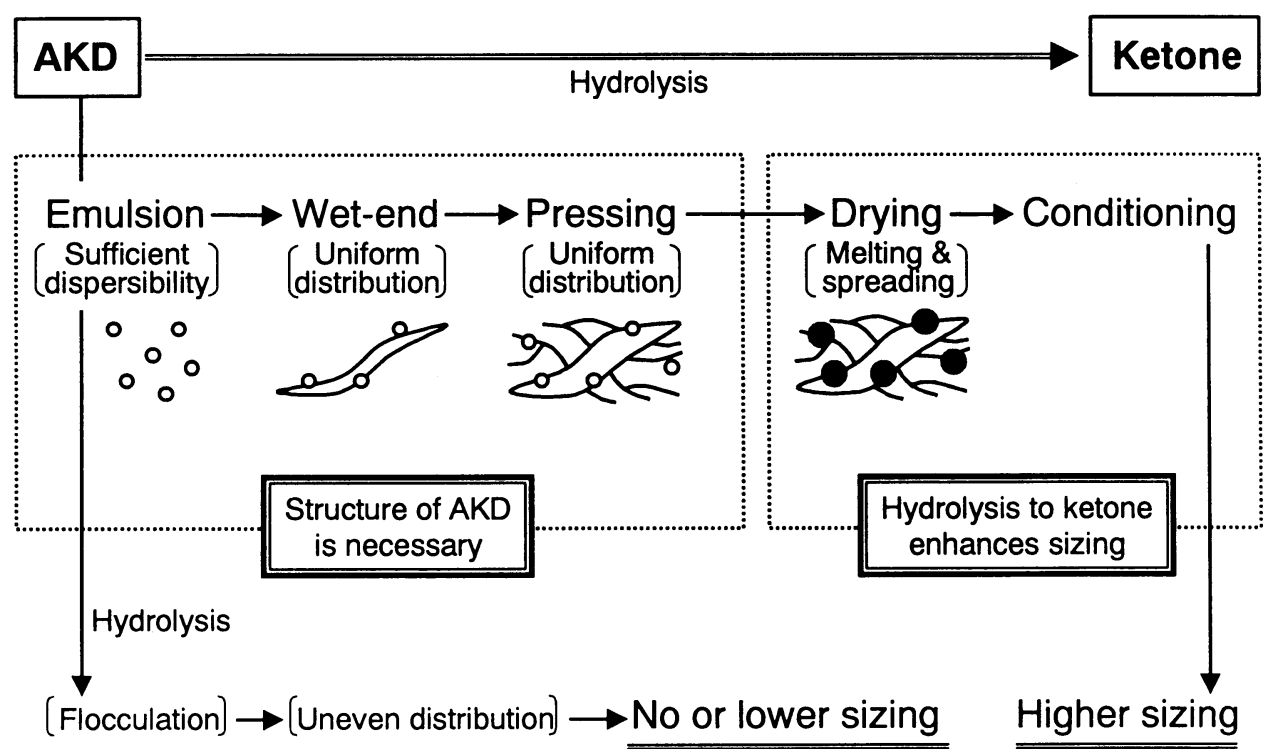

図 $8 \mathrm{AK}$ サイジングに拐ける $\mathrm{AKD}$ とケトンの役割

解によるものと提案されてきた。しかし，このデザイ ジングについても，サイズ剤成分の酸化による親水性 の低下によって説明できる可能性がある。

\section{8.内添サイズ阂による紙のサイズ発現機構}

以上の AKDの結果は, ASA, ロジンソープ，ロ ジンエマルション，ロジンエステル等，AKD 以外の 内添サイズ剤のサイズ発現機構についても当てはまる。 すなわち，疎水性のサイズ剤成分を，親水性のパルプ 纎維表面上にいかに均一に，小さい凝集体として分布 させることができるかによって，効率的なサイズ性の 付与が左右される。AKDやASA では，それらの分 子と水との反応性（加水分解挙動）により, 均一な分 布がより容易に達成され, 加水分解後は疎水性が増加 して水との接触角の増加に寄与する。ロジン等では, ロジンおよび強化ロジン分子中のカルボキシル基が, 親水性部分として機能することにより, サイズ剤成分 の凝集性が抑えられている。しかし，そのカルボキシ ル基の分だけサイズ剤成分の疎水性が低下し，サイズ
骺部分の水に対する接触角 $\theta_{1}$ が小さくなるために, 反応性のサイズ剤に比べて多くの添加量が必要となる。 参考文献

1) Isogai, A. et al. : J. Pulp Paper Sci., 23 (5), J 215 (1997)

2) Isogai, A. et al. : J. Pulp Paper Sci., 23 (6), J 276 (1997)

3) Isogai, A. : "Fundamentals of Papermarking Materials", Pira International, London, Vol.2, p.1047 (1997)

4) Isogai, A. : Proc. 52 nd Appita Annual General Conf., p.71 (1998)

5) Isogai, A. : J. Pulp Paper Sci., in press

6）小野周：「表面張力」共立出版（1980）

7) Roberts, J.C. : "Paper Chemistry", Blackie Academic, London (1996)

8). Scott, W.E. : "Principles of wet end chemistry”, Tappi Press, Atalanta (1996) 